\title{
Filmretorik og den internationale politik
}

\author{
Af Astrid Söderbergh Widding
}

Med baggrund $i$ de seneste års krigs- og terrorhandlinger - Afghanistan, Irak, den 11. september - reflekterer forfatteren over forholdet mellem krig, tilskuer, medier og forestillinger om virkeligheden. Forholdet mellem medier og virkelighed tenderer ifolge forfatteren mod at smelte sammen $i$ en gennemmedieret kultur, hoor fremstillingsformer fra for eksempel film kan anvendes til at formidle faktiske begivenheder. Forfatterens blik på mediekulturen tager afset i flere aktuelle udgivelser fra postmodernismens centrale filosoffer, blandt andet Fean Baudrillard og Paul Virilio. Denne artikel er dermed samtidig en introduktion til deres refleksioner over terrorhandlingerne den 11. september og deres betydning $i$ det moderne samfund.

Vi bør måske skænke amerikansk politiks forhold til filmretorik et par tanker, ikke mindst efter de hændelser, der er indtruffet efter den 11. september 2001. I et klassisk essay fra 1946 skriver den franske filmkritiker og filosof André Bazin, at én af kunstens vigtigste funktioner er at snyde døden ved at skabe udødelighed. Han formulerede hermed den såkaldte "myth of total cinema" - hvilket samtidig er essayets titel - en teori om æstetisk prædestination, hvor filmmediet måske kan opnå, hvad intet andet medium har været i stand til: helt $o g$ fuldstændig at genskabe virkelighed. Retrospektivt kan det vise sig, at Bazin både havde ret og tog fejl i sin profeti; det totale filmmedie eksisterer, men det er ikke filmen. Det er snarere livet selv, som omvendt synes at genskabe filmen, så grænsen mellem film og virkelighed er sløret for altid. Dette gælder ikke mindst på den politiske scene.

I bogen Life: The Movie. How Entertainment Conquered Reality løfter den amerikanske mediekritiker og historiker Neal Gabler arven efter Bazin i en analyse af de faktiske resultater af Ronald Reagans tid som præsident (1981-1989), som ifølge Gabler skal findes inden for filmretorikkens område.

For det første gjorde han [Reagan] filmen til model for offentlig politik. Reagan banede vejen med science fiction-filmplaner som hans Star Wars antimissil program, og med b-film udta- lelser som "They can run, but they can't hide" da arabiske terrorister bortførte luksuskrydseren Achille Lauro og dræbte en amerikansk passager. Herefter kunne house speaker Newt Gingrich i ramme alvor tale om at løse velfærdsproblemet ved at mindes den gamle MGM film Boys Town eller George Bush kunne, da han accepterede opstillingen som republikanernes præsidentkandidat bruge Clint Eastwood-citatet "read my lips" til at sværge på, at han ikke ville hæve skatterne. [...] At forvandle præsidentembedet til en film og politik til eskapisme er ikke noget ringe resultat, men den største arv efter Reagan er måske, at han således fik sat en ny målestok for præsidentens success: præsidentens evner til at begå sig i medierne (Gabler, 1998, s. 113-114).

\section{Golfkrigen og en ny medieretorik}

Det blev almindeligt i medie- og kulturanalyser at anskue Golfkrigen i 1991 som skrevet efter en anden verdenskrigsfilm fra Reagans tidlige Hollywood. Gabler karakteriserer krigen som "tænkt til at være kort og prægnant" med en enkel fortælling, modige helte og en "skurk med overskæg, den irakiske diktator Saddam Hussein, en ond mesterskurk taget ud af den mest simple anti-Nazi propaganda." Han noterer også, at krigen, som vist af de 
konventionelle medier, "endda sluttede som en anden verdenskrigsfilm med tropper, der går i parade ned ad Broadway eller Main Street, overstrøet med graffitti mens de soler sig i deres landsmænds taknemmelighed og sluttekster ruller over skærmen." Analogien kunne trækkes til Golfkrigen, der, selv da den var overstået, "som enhver blockbuster havde sine støttende markeder: byttekort, t-shirts, videoer med kampene" (Gabler, 1998, s.113).

Mange medieforskere og journalister har noteret, at reportager fra Golfkrigen og senere krige er konstrueret som underholdningsprogrammer. Den amerikanske professor i lingvistik, George Lakoff, har analyseret, hvordan adskillige metaforsystemer kunne skelnes blandt tv's dækning af krigens første dage, såsom "eventyret" (der præsenterer soldaterne som helte, våben som magiske og fjenden som dæmonisk), eller "sport" (med citater fra officerer som: "dette er vores Super Bowl", eller "vi er nummer et" fra bombende piloter (Lakoff, 1991). Gabler sammenligner nyhedsdækningen med en tv-serie med logo og musiktemaer (Gabler, 1998, s. 82). Han påpeger også, hvordan et plot bliver konstrueret med for eksempel forskellige titler, og hvordan udsendte journalister blev forvandlet til stjerner, som CNN's Peter Arnett og NBC's Arthur Kent, der fik øgenavnet "Scud stud" ('Scud tyr', red.) efter rapporter om affyring af russiske Scud missiler. Man kan også medregne prisvindende norske krigskorrespondent Åsne Seierstad, som hurtigt blev til "Åsne" for norske tilskuere, men senere blev kritiseret for sin rolle som heltinde i en sæbeopera (“Åsne får kritik, men bara av män,” 2003).

Der er dog én vigtig forskel på disse såkaldte krigsfilm og den klassiske anden verdenskrigsfilm: De gamle var skabt for at støtte krigen. Men hvis krigen selv viser sig at være en film, hvad skal denne krigsfilm da støtte? Neal Gabler foreslår, at vi finder svaret hos Reagan: Den skaber støtte for sig selv. Pointen med Golfkrigen var ikke at befri det besatte Kuwait, sikre oliestrømmen eller udrydde Saddam Hussein, hvilke alle har været nævnt som mulige motiver. Måske er præsident Bush ikke selv klar over det, og det vil måske underminere de legitime risici ved krigen at indrømme det, men det reelle motiv er måske blot at give nationen og den internationale scene en fortælling med en lykkelig slutning. Ikke kun reportager fra fronten, men også websider om krigen bekræfter denne hypotese i deres lovprisning af krigen som en succes med krigshelte, "måske den mest effektive krig i amerikansk historie" (www.indepthinfo.com). Efterhånden som krigen bliver en mediebegivenhed, bliver den også modelleret efter de kendte narrative modeller med almindelige narrative virkemidler.

Golfkrigen og krigene i Afghanistan og Irak deler også en fælles anvendelse af en filmretorik, såsom hyppige deadlines-scenarier. $\mathrm{Og}$ George Bush har specialiseret sig i filmagtige udtalelser, der bliver krigens terminologi, som hans berømte tale om et "korstog" mod terrorisme for at "befri verden fra det Onde" i september 2001. Eller slagord som "Go out there and get them." Først og fremmest ser vi filmretorikken i missionernes kodenavne - som Golfkrigens Desert Storm eller den senere Desert Fox i Irak 1998-99 - der lyder som titler på Hollywoodfilm. Især synes det første kodenavn for den amerikanske operation imod terrorisme - Infinite Fustice (Uendelig Retfærdighed) - dybt ironisk. Tager man dette navn bogstaveligt, er det yderst tvetydigt. Enten betyder det, at amerikanerne har ret til skånselsløst at udrydde ikke bare alle terrorister, men også alle der støtter dem med materiel, moral og ideologi, og at denne proces per definition derfor er uendelig. Eller det betyder, at den udøvede retfærdighed i sandhed må blive uendelig. Den amerikanske kritiker Scott Rosenberg bemærker, at det lyder "som en thriller man ikke ønsker at se, eller et videospil man aldrig kan vinde" (Rosenberg, 2001). Amerikanske islamiske præster indvendte senere, at kun Gud kan udøve uendelig retfærdighed, hvilket den 25. september 2001 førte til en ændring af kodenavnet til Enduring Freedom (Varig Frihed). Eksempler på senere navne på missioner er Valiant Strike (Modigt Angreb, den 16. december 2001) eller Operation Anaconda (den 2. marts 2002). Men strategien fortsætter, som én af præsident Bushs senere retoriske bedrifter indikerer, nemlig det tvetydige "Bring them on" ("Lad dem komme an") fra en tale den 2. juli 2003. Ordvalget blev øjeblikkeligt kritiseret for at være "farlig macho-retorik" af demokraten Dick Gephardt, men det er blot ét eksempel på Bushs række af retoriske udtalelser, der passer langt bedre på B-filmen end på verdensscenen.

\section{Efter den 11. september}

Den mest afgørende begivenhed i denne udvikling af politiske lifies - med Gablers terminologi: livet anvendt som medium for at skrive film (life $\mathrm{og} \mathrm{mo}^{-}$ vies, red.) - blev ikke iscenesat af Hollywood, men påtvunget udefra. Den 11. september markerer et 
vendepunkt, i det mindste symbolsk, der ikke blot fik reaktioner som Infinite Justice-operationerne, men også uendelige kommentarer, fortolkninger og anvendelser, der lader sig opsummere i slagordet: "Intet vil være det samme efter den 11 . september". Forbindelsen mellem Hollywood og den internationale politiske scene blev også bekræftet på unik vis i den såkaldte 'krig mod terror', der fulgte disse hændelser, nemlig da Pentagon i starten af oktober 2001 besluttede at bede Hollywood om hjælp. Tilskyndet af Pentagon blev en gruppe Hollywoodinstruktører og -producenter, hvis speciale var katastrofefilm, bedt om at forestille sig mulige scenarier for terrorisme og dens bekæmpelse. Det kom frem en måned senere, at møderne fortsatte. Målet var, som den slovenske sociolog og filosof Slavoj Zizek formulerede det, at "koordinere krigseffekten og etablere hvordan Hollywood kunne hjælpe 'krigen mod terror' ved at formidle de rigtige ideologiske budskaber til amerikanerne og til Hollywoods publikum verden over." Dette er af gode grunde af kulturteoretikere blevet fortolket som "det ultimative empiriske bevis på, at Hollywood fungerer som 'ideologisk statsapparatus"” (Zizek, 2002, s. 16). Det er kun logisk, at Arnold Schwarzenegger den 4. juli 2003 tog til Irak for at vise sin Terminator 3 som del af sin "Schwarzenegger som guvernør"-kampagne, der viste sig ganske effektiv.

Jeg vil gerne benytte nogen af disse kommentarer som udgangspunkt for de følgende refleksioner, eftersom de var del af at formulere en retorik om den politiske situations betydning, et 'før og efter'. De vil måske være med til at udvikle, hvad professor i statsvidenskab ved University of Hawaii rammende har kaldt "en cinematisk politisk tanke," en måde at tænke politik med filmen som medie eller gennem "et filmisk tankesæt" (Shapiro, 1999, s. 6). På begivenhedens årsdag blev blandt mange ting produceret en film med titlen 11'09"01, September 11: A Film. Blandt de mange instruktører var iraneren Samira Makmalbaf, egypteren Youssef Chahine, Idrissa Oedraogo fra Burkina Faso, englænderen Ken Loach, indiske Mira Nair, amerikaneren Sean Penn og japaneren Shohei Imamura; kort sagt en imponerende liste af kanoniske art cinema-instruktører. I teksterne bliver filmen præsenteret således: "11 instruktører fra forskellige lande og kulturer. 11 visioner af den tragiske hændelse der fandt sted i New York by den 11. september 2001. 11 synspunkter med hver deres subjektive samvittighed. Fuldstændig frihed til at udtrykke sig." Filmen er især interessant som en måde at svare den særdeles visuelle hændelse i en visuel kultur. Tre bøger blev også udgivet af Verso på samme tidspunkt, hvoraf to tidligere var udkommet på fransk. Det var den franske filosof Jean Baudrillards The Spirit of Terrorism (L'esprit du terrorisme, 2002), senere fulgt af hans Power Inferno (2002), Slavoj Zizeks Welcome to the Desert of the Real (2002) og den franske medieteoretiker Paul Virilios Ground Zero (2002), udgivet på fransk samme år med titlen Ce qui arrive. Hver af bøgerne giver på deres vis samtidig et yderst visuelt, eller filmisk, tankesæt. I det følgende vil jeg ikke så meget reflektere over begivenhederne den 11 . september som over deres kulturelle betydning læst igennem disse kommentarer og fortolket fra et visuelt synspunkt.

\section{Billeder af virkeligheden: fiktion, reality-tv og realiteten}

Blandt de tre forfattere viser Paul Virilio det største overblik. Man kan starte med en filmisk reference til Fritz Lang - der en passant bliver nævnt af Virilio, som i sin film om Dr. Mabuse beskriver forbryderens anonymitet, et nyt fænomen i den tidlige modernitet. Forbrydersyndikatet er velorganiseret, men henter sin største støtte i massernes anonymitet. Lang skaber hemmelige forbindelser mellem de anonyme, organiserede kriminelle og politik, mellem videnskab og terrorisme. Den 11. september kan ligeledes anskues som den endelige sejr for denne type anonymitet; privatiseret kriminalitet som udviklingsteoriens ikonoklastiske ypperstepræster havde drømt om i århundrede.

Virilio beskriver ikonoklasmens hærgen under Reformationen i Europa. Med basis i Calvin eller Cromwell finder vi overbevisningen om menneskets negative prædestination, dets ufrivillige underkastelse i en verden behersket af ondskab, hvor livet kan sammenfattes som lidelse eller, med den franske forfatter E.M. Ciorans ord, som "ulempen ved at blive født."

Denne ikonoklastiske bølge ville hærge kulturer og nationer. Ikonoklasternes manikæiske ideer findes også hos videnskabsmænd, der i det tyvende århundrede forsvarede en række evolutionsteorier; teorier om genetik, racehygiejne, frenologi. Eller, med andre ord, overbevisninger der skabte det ideologiske apparatus, der grundlagde det tyvende århundredes totalitære systemer. Kun fremskridtet kan frigøre menneskeheden - dette forbliver en af 
ikonklasternes foretrukne ideer, sammenfattet i en sætning af den franske statsmand François Raspail (1794-1878), ironisk brugt som motto i Ground Zero: "Videnskab, fremtidens eneste religion."

Det tyvende århundredes mørke historie forbliver for Virilio et form for sort hul i udviklingshistorien, hvor videnskabens og teknologiens 'philopholia' - kærligheden til vanviddet - bliver født. I sine yderste konsekvenser vil dette føre til en generations selvudslettelse, fordi den er blevet for langsom, fordi den ikke længere behøver tilpasse sig den øvrige udvikling.

Silvio Berlusconis rolle i international politik, og ikke mindst hans comeback som italiensk statsminister i 2001, er sigende: Den peger på et skifte fra den klassiske opdeling i venstre og højre til en ny adskillelse mellem det politiske og det mediale, hvor de to ofte smelter sammen. Det politisk korrekte er med Virilios ord blevet erstattet af det optisk korrekte. Det parlamentariske demokrati, der reelt var sikret ved folkevalg, er i praksis erstattet af meningsmålingernes direkte demokrati, hvor friheden til at ytre sin mening, til at tilkendegive sin holdning offentligt - eller, at træde ind i den medierede virkelighed - også synes at garantere borgerskab. Edemokrati online er morgendagens slagord.

Og fjernsynets virkelighed, repræsenteret ved reality-tv (som Big Brother eller alle dets slægtninge), er for alvor trådt ind i virkelighedens verden. Ifølge Virilio går der en lige linje fra Big Brother over Kosovo-konflikten til den 11. september; da de alle er produkter af samme multimediebilledstrategi. I Big Brother er målet at vise det virkelige liv og gøre det muligt for enhver at blive stjerne. De virkelige skuespillere er imidlertid ikke realityshowets frivilligt indespærrede på skærmen, men derimod de millioner af tilskuere, der deltager i afstemningen. Med ét er alle kommunikationsmidler tilladte: Hertz-tv, internettet, telefonen, sms. - En måde at udrydde direkte menneskelige relationer og erstatte dem med medierede relationer.

I Kosovokonflikten var målet at skabe en krig uden tab, en krig for specialister. Nu gik det ikke længere ud på at dø i lejre, men at manipulere krigsmaskineriet på sikker afstand. Historiens store kampe er erstattet af verden live med dens mort en direct. Virilio er her enig med Zizek, der mener, at:

... det er ikke bare det, at Hollywood iscenesætter en efterligning af virkeligheden uden materialitetens vægt og inerti - i senkapitalismens konsumsamfund ligner 'det virkelige sociale liv' på en eller anden vis et iscenesat falskeneri med naboer, der i 'virkeligheden' opfører sig som skuespillere og statister (..). Den ultimative sandhed ved det kapitalistiske, utilitaristiske og despiritualiserede univers er dematerialisationen af 'virkeligheden' selv, dens forvandling til en spektral opvisning (Zizek, 2002, s. 13-14).

Således syntes den 11. september også at præsentere en række anonyme skuespillere i, hvad der lignede en global superproduktion; ja, nogen tv-tilskuere opfattede åbenbart først billederne som fiktion. Den franske instruktør Claude Lelouch tager afsæt i en sådan forståelse i sin episode i 11.09.01filmen. I dokumentarstil fortæller han den fiktive historie om en døv fotograf på besøg i New York, hvis kæreste om morgenen den 11. tager afsted på arbejde som guide i World Trade Center. Mens tv'et kører, sidder hun foran computeren og skriver et brev til ham om krisen i deres forhold og fortæller, at hun føler sig "fanget i en spillefilm." Havde hun ænset tv-skærmen, er det klart, at hun alligevel ikke ville have reageret på billederne, eftersom hun var ude af stand til at høre kommentarerne.

Netop fordi begivenhederne den 11. september blev formidlet til de fleste af os via tv-skærmen, var det uundgåeligt, at paralleller blev trukket til Hollywoods katastrofefilm. Med Zizeks formulering: "Det utænkelige, der hændte, var genstand for fantaseren, så på sin vis fik Amerika, hvad det fantaserede om, hvilket var det mest overraskende" (Zizek, 2002, s. 16). Disse paralleller til katastrofefilm blev trukket, uanset om de blev brugt til at forklare begivenheden, anvendt som mulig model for terroristernes handlinger, eller, som i Karl-Heinz Stockhausens kontroversielle udtalelse, tjente til at 'hylde' flyene, der rammer de to tårne, som det ultimative kunstværk. I Stockhausens perspektiv er det som om, vi nu havde set den mest spektakulære special effect nogensinde: selve terroristhandlingen var skabt til at opnå en sådan spektakulær virkning. Og det var som om, at forst efter at have set dette skue blev tilskuere opmærksomme på falskheden ved reality-tv, hvor folk spiller sig selv, og der således er tale om skuespil uanset ambitionen om at gengive virkeligheden. Samtidig bidrog den uendelige gentagelse af de to tårnes kollaps til at fiktionalisere begivenheden. Når vi ser en oplevelse igen og igen, bliver oplevelsen af den virkelige begivenhed gradvis svækket. Oplevelsen af noget unikt, som gentagelsen oprindeligt forsøgte at understrege, bliver 
paradoksalt nok erstattet af oplevelsen af deja-vu, af at se et arkivbillede, der sættes ind $i$ vores uendelige billedbibliotek bestående af ikke mindst de fiktive billeder, enhver tilskuer har. På samme tid er fiktionalisering en del af en abstraktionsproces, der tjener til at fastholde en adskillelse mellem os som tilskuere og dem, de, der var der i virkeligheden. Det virkelige liv antager således en fiktiv dimension.

Den mexicanske instruktør Alejandro Gonzáles Inárrita afviser i sin episode i filmen om den 11. september at være del af denne proces. Hans episode er dén, der mest direkte griber fat om de faktiske hændelser. Første del af det elleve minutter lange bidrag begynder med en fuldstændig sort skærm. På lydsporet er flere stemmer lagt sammen, hvilket er svært at skelne. En monoton recitation, stemmer fra journalister over hele kloden, der på forskellige sprog gengiver førstehåndsindtryk af begivenheden, klip fra personer i de to tårne, der taler i mobiltelefon. Herefter den stigende lyd af et fly og så total tavshed, hvorefter billeder af de sammenstyrtende tårne bliver klippet ind. Lydsporet er dog den væsentligste del af filmen. Mod slutningen bliver de vekslende lyde erstattet af musik, billedet fader over i hvidt med et sidste retorisk spørgsmål: "Vejleder eller blænder Guds lys os?" Gonzáles Inárrita kan kritiseres for at mystificere den Anden med stemmerne på første del af soundtracket, der er uforstålige for de fleste vestlige tilskuere. Jeg finder imidlertid filmen interessant, fordi den næsten fuldstændig trækker sig tilbage fra det visuelle aspekt ved 11. september. Ved at afvise at visualisere begivenheden $\mathrm{i}$ sin helhed, viser filmen den visuelle ordens kollaps konfronteret med det utænkelige. Dette er sandsynligvis, så langt man overhovedet kan fjerne sig fra traditionel Hollywoodretorik - eller fra propagandafilm. Men det er også en måde at indlemme en politisk begivenhed i art cinema-institutionen, og således på paradoksal vis skabe en form for alternativ filmretorik.

\section{Begæret efter Virkeligheden}

Som Jean Baudrillard bemærker i Power Inferno fra oktober 2002 har Slavoj Zizek, som igen henviser til den franske filosof Alain Badios bog Le Siècle, identificeret et eskatologisk begær efter Virkeligheden som et kendetegn ved det tyvende og enogtyvende århundrede. Det er et nostalgisk begær efter Virkeligheden som et mistet objekt, eller i hvert fald et objekt, der er ved at forsvinde. Men dette begær efter
Virkeligheden viser sig dybt paradoksal, fordi den kulminerer i sin tilsyneladende modsætning, nemlig et teatralsk skue. De spektakulære terroristhandlinger kan ifølge Zizek læses som et klimaks og slutpunkt for dette begær efter Virkeligheden i det tyvende århundredes kunst: "Hvis begæret efter Virkeligheden således ender i den rene efterligning af Virkelighedens spektakulære effekt, da, i en nøjagtig omvending, ender det 'postmoderne' begær efter efterligningen som en voldelig tilbagevenden til begæret efter Virkeligheden" (Zizek, 2002, s. 9-10).

Men hvad sker da med den virkelige begivenhed, hvis billedet - det fiktive eller virtuelle - trænger ind i virkeligheden? I dette tilfælde er det risikabelt at betragte begivenheden som en 'virkelig vold', der trænger ind i et potentielt virtuelt univers. Mange proklamerede faktisk slutningen på en postmoderne virtualitet. Men er det her virkeligheden eller historien, der overgå fiktionen? Man kan i stedet sige, at en duel er begyndt mellem virkelighed og billede, en duel om hvilken begivenhed der er mest utænkelig. I tilfældet med de to tårnes sammenstyrtning støtter 'virkeligheden' billedet $\mathrm{i}$ at blive den største angstfaktor. Det er ikke blot skræmmende, men tillige virkeligt. Billedet indtager her førstepladsen, og det virkelige andenpladsen. Noget er blevet tilføjet, der overgår fiktionen selv. Det virkelige er brugt som den ultimative og derfor mest imponerende fiktion.

Den 11. september trådte dette fantasmatiske skærmbillede ind i virkeligheden. Det var ikke virkeligheden, der trådte ind i billedet, som mange påstod. Tværtimod erobrede billedet virkeligheden og knuste den. At mange amerikanske film med scener, der lignede de to tårnes kollaps, blev udskudt, skal ikke læses som et tegn på respekt for ofrene, men først og fremmest som en undertrykkelse af de kulturelle fantasier, der skabte en stærk baggrund for katastrofen. Det er ikke, hvad Roland Barthes i et berømt essay fra 1960 kaldte l'effet du réel, men snarere modsætningen, l'effet de l'irréel, hvor - med Zizeks ord - det Reelle selv, for fortsat at eksistere, må forstås som mareridtets uvirkelige spøgelse. Det er heller ikke den hyppige formaning om ikke at forveksle fiktionen med virkelighed. Snarere det modsatte: Spørgsmålet er ikke at forveksle virkeligheden med fiktion, "men at være i stand til at adskille dét, vi kun kan opleve som en fiktion, nemlig den hårde kerne af Virkelighed, som vi kun kan udholde, hvis vi er i stand til at fiktionalisere den" (Zizek, 2002, s. 19). 
Selve begivenheden modstår repræsentation. For det forste fordi den synes at absorbere vores forestillingsevne, og for det andet fordi den ikke giver nogen mening. Dette er nøjagtig, hvad Gonzáles Inárritas film understreger. De to tårnes sammenstyrtning fik ikke verdensordenen til at styrte sammen, hverken politisk eller økonomisk. På sin vis betød dette billedets fallit. Baudrillard har fremsat det argument, at systemet ikke kan fungere, hvis ikke det kan måle sig med sit eget billede, spejle sig som de to tårne i en perfekt symmetri, eller finde sin balance i en ideel reference. Det er, hvad der gør systemet usårlig, og det er netop denne balance, der blev ødelagt.

Terrorismens vold betyder således ikke, at hverken historien eller virkelighedens flamme vender tilbage. Volden er ikke 'virkelig' - eller i hvert fald mere end det. På sin vis er den værre: den er symbolsk, hvilket gør det muligt for den at blive enestående. Og i denne enestående blanding, i denne Manhattan-katastrofefilm, bliver et møde opført mellem "det tyvende århundredes to største genstande for fascination. Det er filmens hvide magi - eller hvide lys - og terrorismens sorte magi - eller sorte lys - der også opføres symbolsk i Gonzáles Inárritas film (Baudrillard, 2002 (1), s. 40).

Det er omsonst at søge en forklaring på den terroristiske handling. Trods alle forsøg på at forklare eller forstå terroristhandlinger, om det er fra et historisk, geografisk, kulturelt eller religiøst synspunkt, så modsætter selve handlingen sig fortolkning. At 'forstå' terrorhandlingers mulige motiver fører ikke til at 'forstå' deres konsekvenser. Skuets radikalitet ligger lige præcis i fraværet af enhver fortolkning eller forståelse. Terrorismens skue påtvinger os skuets terrorisme. En konsekvens af dette er, at man kan argumentere for, at ideen om at "terrorisme ville intet være uden medierne" er illusorisk. Simpelthen fordi der ikke findes nogen 'god' måde at rapportere begivenheden i medierne, eftersom medierne ikke kan undgå at blive del af begivenhederne (Baudrillard, 2002 (1), s. 41).

\section{Fortrængning og genkomst}

I sit bidrag til 11.09.01 kommenterer den israelske instruktør Amos Gitaï den uundgåelige sammenfletning af terrorismens skue og medierne. Alt begynder som i en actionfilm. Først lyden af en bombe mens billedet er sort. Dernæst en person klædt i militærtøj, der skriger: "Ryd området! Der kan være flere bomber!" Minutter senere træder en journalist ind på scenen, og genren synes at skifte til dokumentar. Hun vil rapportere live om terroristhandlinger i Tel Aviv på Jerusalem Avenue, men hun opdager, at hun er taget af sin tidligere 'on the air'-position på grund af et eller andet i det fjerne New York. "Hvem fanden interesserer sig for New York?" Da den hysteriske reporter omsider forstår, at en katastrofe finder sted derovre, bryder hun sin liste over historiske begivenheder den 11. september ved at sige, at: "i dag står to terroristhandlinger side om side." Tel Aviv ved siden af New York. Hendes udsagn er mindre absurd, end det umiddelbart synes, for det stiller en kontinuerlig scene for terrorisme (Jerusalem) over for en enkelt spektakulær begivenhed (New York).

Terrorismens sejr er dobbelt: Først tillader den et udbrud af det fortrængte, der nu er uden for kontrol, hvilket ikke mindst den aktuelle situation i Israel og Palæstina viser. Dernæst legitimerer den nye terroristhandlinger ad infinitum. Men dette fører også til, at alle andre voldshandlinger lader sig underordne terroristerne. Det er kaldt "terrorismens automatskrivning", næret og vedligeholdt af "den utilsigtede terrorisme ved informationer", støttet af filmretorik, med den fulde konsekvens af alle former for panik. Som svar byder krig blot på endnu en situation med fantominformation og bedragerisk diskurs - dette gælder såvel Golfkrigen som krigen i Afghanistan eller krigen i Irak (Baudrillard, 2002 (1), s. 45).

I den ny globale verdensorden findes ikke længere krige, i hvert fald ikke i traditionel forstand, som regulerede konflikter mellem suveræne stater. Der er "etnisk-religiøse konflikter" eller angreb på USA - og når USA svarer på disse angreb, har det overtaget rollen som den suveræne forsvarer af fred og global orden, der knuser bestemte oprør. Modsætningen mellem krig og humanitær hjælp er forsvundet; de to er tæt forbundne, fordi - som mange bemærkede under krigen i Afghanistan - det samme fly nu kaster både bomber og madforsyninger. Men adskillelsen mellem krig og fred er også blevet udvisket, som når præsident Bush efter den 11. september erklærer, at: "Amerika er i krig." Ligesom freden i Irak, udråbt af Bush i maj 2003, kun er fulgt af flere amerikanske tab, reelle såvel som symbolske, end under selve krigen.

Målet for krigen i Afghanistan eller Irak kan defineres som primært rettet mod 'normalisering', snarere end et politisk eller økonomisk mål. Den 
udbredte ide med denne normalisering er globalisering. At stille alle territorier på række, bringe dem på linje, reducere enhver modstand til en zone, kolonisere ethvert vildt område, hvad enten det er geografisk eller mentalt. Enhver modstand er således per definition terroristisk. Moderniteten tillader ikke sig selv at give afkald på sin aspiration imod global udspredelse (Baudrillard, 2002 (2), s. 76, 78).

Foråret 2002 blev krigen i Afghanistan (og til en vis udstrækning begivenhederne den 11 . september) skubbet i baggrunden af den israelskpalæstinensiske konflikt. I foråret 2003 blev krigen i Irak derefter hovedbegivenheden, og konflikten i Israel-Palæstina trådte i baggrunden. På et tidspunkt under krigen skete det modsatte igen: Konflikten i Irak blev utydelig, da Saddam Hussein syntes at være forsvundet ud i den tynde luft, og de kemiske våben ikke blev fundet. Fortællingen var ikke længere så tydelig, som en krigsfilm i det virkelige liv kræver. Derfor blev der lavet en lykkelig slutning med amerikanske befriere og jublende irakere i gaderne, dog tilsat en vis undren over irakernes manglende taknemmelighed overfor deres befriere. Så skiftede fokus igen til selvmordsbomber i Palæstina, og til deres tjetjenske modpart i Rusland. Siden den officielle fredsdeklaration den 1. maj 2003 er den fortsatte krig i Irak med stigende amerikanske tab og manglende beviser for eksistensen af masseødelæggelsesvåben en kilde til stadig irritation for præsident Bush, fordi den ødelægger den ellers simple konflikt.

Medieretorikken og dens skiftende fokus er ikke uskyldig. Den beskriver tværtimod igen og igen forestillingen om et civilisationernes sammenstød, som professor ved statsvidenskab i Harvard, Samuel P. Huntington, har kaldt den primære politiske kamp i det enogtyvende århundrede. En ide, Michael J. Shapiro med stor energi har argumenteret imod:

Den 'virkelighed', Huntington skaber med sin 'Vesten mod resten af verden', gør kloden til en moralsk geografi, et sikkerheds-orienteret etniskpolitisk initiativ, der skal beskytte en enklave, hvis civilisatoriske integritet mere udspringer af den måde, hvorpå han fortæller historien om moderniteten, end af synlige kulturelle eller civilisatoriske forskelle (Shapiro, 1999, s. 119).

En sådan forestilling om 'civilisationernes kamp' er mystificerende snarere end opklarende. Den centrale kamp synes at finde sted i hver enkelt civilisation, snarere end mellem dem. Ud fra Shapiros kritik kan man argumentere for, at de såkaldte civilisationskampe i dag kan identificeres som kampe i den vestlige globale kapitalisme. Vi er vidne til en række virkelige kampe forbundet med globalisering. Der er et økonomisk motiv bag konflikterne: De viser sig at være den vestlige kapitalismes økonomiske eller geopolitiske interesser.

I sine bøger forsøger Jean Baudrillard netop at vise, at den terroristiske handling rækker ud over sin egen spektakulære vold, endda ud over islam og ud over USA og mulige civilisationskampe. Han ser terrorismen som afdækningen af en radikal modsætning i selve globaliseringsprocessens hjerte, fremkomsten af en ustoppelig kraft midt i den tekniske og mentale fremdrift, en kraft, som forstyrrer den tilsyneladende uomgængelige evolution mod en stadig mere perfekt og komplet verdensorden (Baudrillard, 2002 (2), s. 36). Det er, som om verden selv modsætter sig globalisering.

\section{Det globale over for det universelle}

Globalisering berører først og fremmest markedet, men påvirker også tegn og værdier i kulturen. Dermed er der ikke længere en klar forskel på det globale og det universelle. De såkaldt universelle værdier er blevet globaliserede og cirkulerer markedet ligesom ethvert andet produkt. Der er en bevidst forvirring her mellem de to koncepter 'global' og 'universel'. I dag kunne eller skulle - som Zizek mener - det universelle være defineret som den umulige eller i det mindste uendelig opgave at oversætte for at skabe et fælles forståelsesrum imellem kulturerne. Men det er nøjagtig denne 'universalitet', der hele tiden bliver erstattet af 'globalisering'. Modstanden mod globalisering skal forstås ikke bare som en modstand mod den globale teknostruktur, men også som en afvisning af det mentale billede, der følger med, og som opsluger alle kulturer med den falske påstand at betragte dem alle som ligeværdige. For at begynde hvor vi sluttede, og for at parafrasere Bazin, så er det ikke længere et spørgsmål om myten om den totale film, men myten om den globale film. Denne globale film projiceres i det uendelige på vores kulturskærme, hvor den tilbyder os den samme gamle fortælling om globale værdier, om at være truet af en ildevarslende agent udefra i forskellige versioner af Det Absolut Onde, som vi trofaste filmgængere kun kender alt for godt. 


\section{Litteratur}

Åsne får kritik, men bara av män. (2003, August 17). Aftonbladet.

Baudrillard, J. (2002). L'esprit du terrorisme. Paris: Galilée.

Baudrillard, J. (2002). Power Inferno. Paris: Galilée.

Bazin, A. (1958). Qu'est-ce que le cinéma I. Paris: Les Éditions du Cerf.

Gabler N. (1998). Life: The Movie, How Entertainment Conquered Reality. New York: Vintage Books.

Lakoff, G. (1991). Metaphor and War: The Metaphor System Used to Fustify War in the Gulf. Paper præsenteret på UC Berkeley, 30. januar.

Rosenberg, S. (2001, 20. september). Infinite justice. Hen- tet fra http://dir.salon.com/news/feature/2001/09/ 20/infinite_justice/index.html.

Shapiro, M.J. (1999). Cinematic Political Thought, Narrating Race, Nation and Gender. Edinburgh: Edinburgh University Press.

Virilio, P. (2002). Ce qui arrive. Paris: Galilée.

Zizek S. (2002). Welcome to the Desert of the Real. London/ New York: Verso.

Astrid Söderbergh Widding er professor i filmvidenskab på Stockholms Universitet, Sverige. 